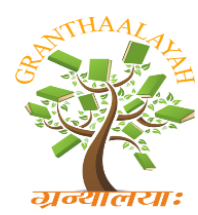

INTERNATIONAL JOURNAL OF RESEARCH GRANTHAALAYAH

A knowledge Repository

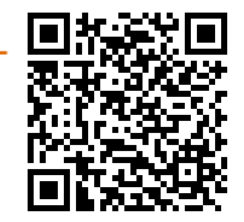

Social

\title{
AN ANALYSIS OF SIDDHARTHA'S QUEST FOR MOKSA IN HESSE'S NOVEL THROUGH THE LENS OF HINDUISM
}

\author{
Techapon Saengwong ${ }^{* 1}$, Prommintra Kongkaew ${ }^{2}$ \\ ${ }^{*}{ }_{1,2}$ English Department, Graduate School, Ubon Ratchathani Rajabhat University, THAILAND
}

\begin{abstract}
The purposes of the study were to examine the concept of the quest for spiritual liberation of Hinduism and to analyze Siddhartha's quest for moksa in Hesse's novel that accords with the concept of Hinduism. The text used to analyze is Hesse's novel, Siddhartha. The study found that Siddhartha's quest for moksa is consistent with the concept on the quest for spiritual liberation of Hinduism in three aspects. Firstly, Siddhartha's quest depicts the four stages of life as related to ages and duties (asramas), namely, religious student (brahmacarya), householder (grhastha), forest-dweller (vanaprastha), and renunciant (sannyasin). Secondly, the quest of the protagonist presents the pursuit of the four objectives of life (purusharthas) comprising sensual pleasures (kama), wealth (artha), righteousness and duty (dharma), and liberation (moksa). Finally, Siddhartha's quest also portrays the means to liberation through the path of knowledge (jnana-marga) divided into two stages, viz., cultivation of detachment (vairagya) and acquisition of knowledge (jnana).
\end{abstract}

Keywords:

Hinduism; Siddhartha; moksa; asramas; purusharthas; jnana-marga.

Cite This Article: Techapon Saengwong, and Prommintra Kongkaew, "AN ANALYSIS OF SIDDHARTHA'S QUEST FOR MOKSA IN HESSE'S NOVEL THROUGH THE LENS OF HINDUISM" International Journal of Research - Granthaalayah, Vol. 4, No. 3 (2016): 192-204.

\section{INTRODUCTION}

The world today is fast changing materially, socially, politically, and culturally. It is very important that humans adjust themselves accordingly. Otherwise, they will find it hard to live.

It is noticeable that the changes which have been taking place are mainly concerned with physical aspects. Every day we see new buildings, new innovations, and new technology. We have to accept that "these physical aspects are inescapable and necessary to our lives."[17] Unfortunately, "humans give priority or attention to material growth at the expense of the spiritual aspects."[14] People are pursuing happiness and pleasures based on material possession. They seem to forget that being human comprises two components: physical and spiritual. It is not 
possible to live life only one part without caring about the other. Sadly, the more they pursue, the more distant they become from the truth about these components.

In the chaotic world today, many people begin to ask the question on the physical element as to whether it can really satisfy their needs or goals. The other side which is mainly neglected is the spiritual side. Although this is very essential to humans, they are not aware of it. This blindness gradually stimulates human greed for gaining more material things in order to fulfill the desires. As a consequence, "the greedy and excessive quest for riches and joy cause suffering and disorder.'"[3]

We have to accept that we cannot grow on bread alone. We have to cultivate a spiritual development as well. The tension between spirituality and materialism has been played out thoroughly the mind of many people for a long time. And still the question is: Should people ignore and withdraw from materialism and insist on spirituality? At this point, the best answer for this question is spirituality and materialism should not be divided. "Human should keep materialism and its real utilities in order to gain spiritual progress although materialism has to be abandoned in the end."[1]

The quest for spiritual liberation is central to Hinduism. This religious practice is intended to explore the path to moksa or the state of being free from suffering. As dealing with the perpetual and eternal facts of life, "Hinduism views that the existence of human being is not the real freedom. It is still subject to bondages, viz. avidya, karma and samsara and needs deliverance."[10] "These bondages are the major obstacles that prevent us from seeing the fullness of life other than our worldly and materialistic life."[2] The quest for spiritual liberation, therefore, is the process of ending human bondages and becoming the Perfect human through spiritual practices.

As the quest for liberation is vital to humans, the research is intended to study concepts regarding spiritual quest for moksa of Hinduism and to analyze how these concepts are presented in the novel Siddhartha.

\section{CONTEXT}

\section{ASRAMAS OR FOUR STAGES OF LIFE}

Hinduism divides human life-course into four steps related to ages and duties. These stages are symbolized as religious student (brahmacarya), householder (grhastha), forest-dweller (vanaprastha), and renunciant (sannyasin). "The four asramas transform humans, take them to perfection stage by stage, and the practice of the four asramas manages the life from childhood to old age.’[15]

\section{Religious Student or Brahmacarya}

"The Student stage or brahmacarya asrama begins at the age between eight and twelve after the rite of initiation and lasts for twelve years."[16] It is the period of study and discipline under the guidance of a spiritual teacher. "The young Brahmin devotes most of his time in study and leads an ascetic life during the years of studentship.'[6] He lives in the family of his spiritual teacher 
and serves him in various ways for what he is instructed. "He studies the holy texts, gain discipline, learns required skills to discharge ritual function, and prepares for the future life."[10]

\section{Householder or Grhastha}

After he has completed his studentship, the individual then carries on the second duty of life at the age of twenty-five. While brahmacarya asrama lays great emphasis on religious study and self-discipline, grhastha asrama proposes that "the Householder stage is spent to pursue the enjoyment of life."[7] However, the individual also needs to adopt all the duties and responsibilities of a householder as well. "The householder gets married, finds a job, procreates children, and accomplishes social duties."[2] In short, he has obligations not only towards his family but also towards the community he belongs to. "This has been concluded that the householder has to play with the three fronts: family, vocation, and society."[16] Therefore, grhastha is considered to be the backbone of the Hindu community because "he supports other people.’[15]

\section{Forest-Dweller or Vanaprasthya}

While grhastha asrama proposes the three realms: family, vocation, and society as mandatory for a householder, vanaprasthya asrama in contrast emphasizes the abandonment of secular duties and responsibilities. "This stage begins when hair turns grey, skin wrinkles, and grandchildren arrive."[2] An aged person, after discharging all the duties and responsibilities of a grhastha, has to put aside all worldly possessions and concerns and resign into the forest or solitary place. "His wife may stay with her children or follow him."[15] He is now free from duties of life and social bondage. Like brahmacarya asrama, vanaprasthya asrama is only a preparation for the complete renunciation. The forest-dweller devotes himself to spiritual study and discipline under the guidance of a spiritual teacher, "starts the difficult inner pursuit", [18] and "practices meditation in order to unite his soul with God."[9]

\section{Renunciant or Sannyasin}

For Hindus, sannyasin asrama is the stage of complete renunciation. This stage aims at the quest for moksa or liberation. A sannyasin has no home and possession. He wanders as a beggar from one place to the next until he dies. "He forgoes all man-made customs and conventions."[15] Sannyasin asrama prescribes that the life of a sannyasin is devoted to meditation practice. Moreover, "he is universally consigned to love, instruct, and help anyone he find on his life's way.'[2]

Since asramas deal with the four successive human life-courses as related to ages and duties, it is interesting to search other concepts which relate to the quest for moksha suggested by Hinduism.

\section{PURUSHARTHAS OR FOUR AIMS OF LIFE}

Hinduism has the tradition to look at life through the four aims called in Sanskrit as "purusharthas" which literally means good things for human beings. These four aims include worldly and spiritual dimensions altogether. Hinduism holds that if an individual is to find the true happiness and fulfillment, he has to follow these four aims. Purusharthas comprises sensual pleasures or kama, wealth or artha, duty and righteousness or dharma, and liberation or moksha. 


\section{Sensual Pleasures or Kama}

The first objective of life found in purusharthas is kama. "The word is roughly translated as desire, pleasure, lust, and love."'[4] "Kama, in the widest meaning, denotes desire and the object of desire. It, in a narrow meaning, refers to erotic or sexual love.'[12] On the whole, kama has the meaning wider than sex. It is the enjoyment of anything which can be experienced through human senses. "It includes the enjoyment of aesthetic appreciation, eating fine food, or of anything related to good living."[13] "As far as it is done morally, humans should enjoy kama at the proper age."[11]

\section{Wealth or Artha}

Artha is one of the objectives of life proposed by Hinduism. "This word means things, object, and substance which can be possessed, enjoyed, and lost, and which individuals need in daily life for maintaining a household and discharging of religious duties."[18] In the widest sense, it refers to worldly achievement. Humans naturally pursue artha not only because it generates a comfortable life, dignity, and self-respect but because "without artha, they cannot discharge religious duties such as the performance of rites, feeding renouncers, and involving in charitable activities.’[12]

\section{Duty and Righteousness or Dharma}

The word "dharma" has a variety of meanings. "It denotes moral responsibility, right doing, uprightness, adherence to moral law, and much else."[8] Dharma thus comprises the entire context of moral and religious obligations. It is the highest of worldly goals. "The aim of dharma needs that humans be mindful to the well-being of the entirety."[3] It is believed that dharma is the means to the highest end of life or moksha. "Dharma can be roughly classified into six categories: (1) dharma as the cosmic impersonal law or rita; (2) dharma as laws of nature; (3) dharma as essential property/disposition; (4) dharma as social/moral norms; (5) dharma as duty/obligation; and (6) dharma as virtue."[12]

\section{Liberation or Moksha}

Among the four legitimate goals of human life, moksha is regarded as the highest end. "The word means liberation, escape, freedom, release; rescue, deliverance; final emancipation of the soul."[18] Moksha generally denotes the state of being liberated or the process of becoming free. This state is the consequence of the right understanding of the true self. "Such an understanding of the true nature of the self terminates the cycle of death, birth, and rebirth."[3] "There are many arguments about the exact nature of moksha. This is roughly classified as: (1) Moksha is the state of positive bliss (ananda); (2) Moksha is the state of absent of pain and suffering; (3) Moksha is the state of uniting with Brahman; and (4) Moksha is the state of remaining nearer to God."[12] However, it is commonly accepted that one can attain moksha while living. In the context of purushartha, "moksha defines the duty that one must pursue to discover the true fulfillment in which one has to experience by direct realization in order to be released from samsara and achieve spiritual liberation.’'[10]

Besides asramas which deal with the four stages of life and purushathas which suggest four good things for human beings, it is essential to look for the means to moksha suggested by Hinduism. 


\section{Jnana-marga or the path of knowledge}

According to traditional Hinduism, there are three paths leading to liberation: karma-marga or the path of work, bhakti-marga or the path of love and devotion, and jnana-marga or the path of knowledge.

"Jnana-marga is the way to unity with Brahman through knowledge intended for spiritual aspirants who have a strong reflective incline."[16] Due to avidya or ignorance, an individual thinks that he is separate from Brahman. This prevents him from knowing his true nature. The knowledge here comes in to remove this ignorance. However, this knowledge is not factual information. It denotes "the realization of the sameness of the individual soul with the Supreme Soul or Brahman.'[15] The practice of jnana-marga is intended to achieve this knowledge.

The practice of jnana-marga, on the whole, comprises two stages viz., cultivation of detachment (vairagya) and acquisition of knowledge (jnana). In the first stage, "the aspirant of jnana-marga practices the four means, viz., discrimination (Viveka), dispassion (Vairagya), the sixfold virtues (Shat-Sampat) -- viz., tranquility (Sama), restraint (Dama), Satiety or renunciation (Uparati), endurance (Titiksha), faith (Sraddha) and concentration (Samadhana) -- and strong yearning for liberation (Mumukshutva)."[15] "These activities are intended to purify and provide a foundation for deep and profound experience.’'[10]

In the second stage, the acquisition of knowledge (jnana) requires three steps, namely, hearing, reflection, and meditation. "The aspirant listens to the sacred texts by sitting at the lotus-feet of a spiritual teacher. He then practices reflection which entirely eliminates all doubts. Afterward, he practices deep meditation on Brahman and achieves Brahma-Sakshatkara.'[15] The aspirant finally becomes a liberated sage or a Jivanmukti.

\section{Asramas as the backbone of Siddhartha}

In Siddhartha (2006), a novel by Hermann Hesse translated from German to English by Hilda Rosner, the quest of the eponymous protagonist of this novel, depicts asramas as related to his ages and duties. Asramas founded in Siddhartha can be classified into four stages, namely, the religious student stage (brahmacarya asrama), the householder stage (grhastha asrama), the forest-dweller stage (vanaprasthya asrama), and the renunciant stage (sannyasin asrama).

\section{Siddhartha as a brahmacarya}

Brahmacarya asrama is presented through the act of the protagonist in terms of his studentship. Siddhartha, a Brahmin's son, firstly equips himself with religious study and discipline in the context of Brahmanism. "Siddhartha had been partaking in the conversations of the learned men, engaging in debate with Govinda, practicing with him the art of contemplation and meditation."[5] At the beginning of Chapter 1, the protagonist is portrayed as a religious student who learns and practices the art of Brahmins as regulated by brahmacarya asrama. He studies the Vedas, learns necessary skills for ritual functions, and prepares for his future life.

After leaving his father to join the sramanas, the protagonist continues his further religious study in the context of asceticism in Chapter 2. "Siddhartha learned a lot from what the Samanas instructed; he learned many ways to go away from the Self. He went along the way of self-denial by the means of pain, through voluntarily suffering and overcoming pain, hunger, thirst and 
exhaustion."[5] This, according to brahmacarya asrama, is considered to be living in the family of his spiritual guru where asceticism becomes his study and discipline.

In the first stage, the protagonist's duties and ages are related to religious study and discipline as regulated by brahmacarya asrama. He first studies with Brahmins and then shifts his study to the context of asceticism where he lives in the family of a spiritual guru, and studies the art of sramana.

\section{Siddhartha as a grhastha}

After completing the stage of a brahmacarya, the protagonist sets off to the town where he participates in worldly activities and lives a mundane life. In this second stage, the protagonist has participated in the three realms: family, vocation, and community.

In the aspect of his family, Kamala, a beautiful courtesan, has become his lover. Siddhartha spends his time and enjoys himself with her. He lays great emphasis on Kamala and regards her as his wife. "Wonderful hours were spent with the beautiful and smart courtesan. She became his teacher, his lover, and his friend. The purpose and value of his present life was laid here with Kamala.'[5] Moreover, his relationship with Kamala also represents the duty of a husband and wife in giving advice to each other. This is essential in maintaining the household. "He usually came back to the beautiful Kamala from whom he learned the art of love. More than anything else, he learned that giving and taking become one. He learned from her, talked to her, gave her advice, received advice.’[5]

In the aspect of his vocation, Siddhartha gets his job by the ability that he learned when he was a brahmacarya. He works with Kamaswami, a local businessman who gave a lot of trust to Siddhartha. "The merchant passed on duties of writing important letters and orders to him. He got into the habit of discussing all important affairs with him."'[5] Afterward he earns his living by becoming a merchant who runs the business within the appropriate bounds. "He accepted the profit he made with equanimity. He laughed and said, 'Well, this transaction turned out badly' when he made losses.'”[5]

In the third aspect, the protagonist discharges the duties and responsibilities of a householder to a community he belongs to by supporting the others. "And there were many people coming to him. They came to do business with him, to cheat him, to listen to him, to exploit his sympathy, to get his advice. He gave advice, he pitied, he gave gift, he let them cheat him a bit."[5] Furthermore, these duties and responsibilities also connote that he, as a householder, is the backbone of a community.

In this second stage, the protagonist has fulfilled the obligations of a grhastha as regulated in brahmacarya asrama. He devotes his time to the enjoyment of life and duties. These worldly activities are related to the three fronts: family, vocation, and community.

\section{Siddhartha as a vanaprasthya}

In the third stage, vanaprasthya asrama is presented through the act of his retirement to the forest for pursuing higher spiritual things. After the protagonist is aware of his old age "when he found his face to have aged and became more ugly in the mirror of his bedroom's wall", [5] he 
gradually realizes that his householder life has come to an end. "Then, Siddhartha realized that the game was over, that he could play it any more."[5] Therefore, the act of his departure at the end of Chapter 7 connotes the abandonment of worldly possessions and concerns.

When Siddhartha reaches the river bank considered to be a solitary place for a forest-dweller and decides to learn the secrets of the river, he reunites with Vasudeva, a ferryman who then plays the role of his spiritual guru. Living by the river bank with Vasudeva, Siddhartha has become a vanaprasthya symbolized as a ferryman. At this stage, he is free from duties of life and social bounds. "Siddhartha stayed with the ferryman. He learned how to take care of the boat. He worked with Vasudeva in the rice field when there was nothing to do at the ferry."[5] Moreover, the main duty of a forest-dweller is also emphasized as well. That is: he devotes his time in spiritual study and discipline. "Most of all, he learned how to listen from the river, to listen with a quiet heart, with a waiting, opened soul, without feeling, without a wish, without judgment, without an opinion.'[5] This act can denote the practice of difficult inward quest.

The act of the protagonist in this stage represents what vanaprasthya asrama regulates. He renounces worldly possessions and concerns, and retires to the solitary place. There he spends his time in spiritual study and discipline under the guidance of Vasudeva, preparing himself for the final stage.

\section{Siddhartha as a sannyasin}

After Kamala's death, Siddhartha, an old man, tries to raise his spoiled and stubborn son although Vasudeva suggests taking the boy to the town. One day, the boy has fled from his father. Siddhartha sets off to try to find and bring his son back, but his effort is useless. He cannot find his son in the town, and this makes him suffer tremendously.

While Siddhartha suffers from the boy's disappearance, he gradually realizes that his suffering is the retribution of his own karma --an offense he once committed against his father. This encourages him to accomplish the duty of a sannysin. Siddhartha starts his spiritual practice under the guidance of Vasudeva again. "When he neither listened to the laughter nor the sorrow, when he did not tie his soul to any particular voice and let his Self-submerged into it, but when he heard them all, the oneness; then the great song of a thousand voices consisted of a single word: Om -- perfection."[5] The practice of meditation symbolized as listening to the river gradually dispels his attachment and finally secures him the right understanding of the knowledge of the self. This attainment, according to sannyasin asrama, connotes the final emancipation of the soul and also marks the stage of complete renunciation.

In the second half of this stage, the protagonist stays by the river and carries on the duty of a ferryman. He devotes his time helping people symbolizing as taking people across the river. He also discharges the role of a spiritual guru by teaching the Knowledge of the Self to Govinda. "Unlike knowledge, wisdom cannot be conveyed. One cannot express wisdom in words and teaching although it can be discovered and experienced."[5] He then concludes that "In deep meditation, time can be eliminated. All the past, present, and future can be seen at the same time, and then everything is good and perfect. Everything is Brahman."[5] This emphasizes selfexperience as the essence of his teaching. In the end, after kissing Siddhartha's forehead, 
Govinda directly realizes that the Self dwells in everything. This direct realization secures him spiritual liberation.

The duties of a sannyasin in the first half of this stage are depicted through his the quest for moksha and complete renunciation. In the second half of this stage, Siddhartha after achieving enlightenment discharges the duties of a sannyasin by teaching and helping Govinda.

Siddhartha obviously represents the four stages of life or asramas. The protagonist, in his different stages of life, fulfills his duties prescribed by the four asramas. He lives a life of a religious student first, and then spends his second stage of life partaking in three realms: family, vocation, and community. In the third stage, he retires to the forest to live a life of a forestdweller. Finally, he completes the last stage of life by discharging the duties of a renunicant. These four stages are considered to be the backbone of Siddhartha's quest.

\section{Purusharthas as the objectives of Siddhartha's quest}

While Siddhartha's stages of life depict the duties in different ages, his quest also represents the pursuit of four objectives as regulated by Hinduism. Purusharthas founded in Siddhartha can be classified into four things, namely, wealth or artha, sensual pleasures or kama, duty and righteousness or dharma, and liberation or moksha.

\section{The pursuit of kama in Siddhartha}

The pursuit of kama represented in Siddhartha begins when the protagonist is in the stage of puberty which, according to purushartha, is the proper time to pursue kama. Siddhartha begins to get involved with sensual pleasures through the desire to explore love with Kamala. This courtesan is considered to be a personification of kama. Therefore, the involvement with Kamala connotes the pursuit of kama through the enjoyment of sensual pleasures which comes out in the form of sex. "They played one of the thirty or forty different love games which Kamala knew. Her body was flexible as if it was a jaguar and the bow of a hunter. He who had learned how to make love from her was knowledgeable of pleasures, of many secrets."[5]

The protagonist also pursues and experiences kama through other kinds of worldly enjoyments. This emphasizes that sensual pleasures have the meaning broader than sex. Kama includes anything involved with good living. "He had learned many things: to wear beautiful clothes, to give orders to servants, to bathe in fragrant waters, and to eat sweet and tenderly prepared foods." [5] These acts clearly show the broader concept on the pursuit of kama which, on the whole, can be experienced through the senses.

As kama connotes the enjoyment of anything which can be experienced through the senses, the pursuit of kama in Siddhartha not only represents the enjoyment of kama through sex, but also through good living.

\section{The pursuit of artha in Siddhartha}

Another prominent objective sought by the protagonist is wealth or artha. Like Kamala, Kamaswami, the richest merchant in the town, is the personification of artha. Therefore, working with Kamaswami connotes the pursuit of artha which firstly confers a comfortable life to the protagonist. "Now, he lived in the merchant's house. He got clothes and shoes. A servant prepared him a bath every day. Fine food was served two times a day."[5] 
Besides securing a comfortable life regarded as the legitimate requirement of human nature, artha also generates dignity and self-respect. This idea represents in Siddhartha's response to Kamaswami's reproach: "If a loss has occurred, let me bear the loss. This trip really satisfied me. I have become familiar with many kinds of people, a Brahmin had become my friend, children sat on my knees, peasants have showed their fields to me. Nobody thought I am a merchant."[5] His confidence and self-esteem in the passage state clearly that the pursuit of artha to some extent generates the sense of dignity and self-respect.

Moreover, wealth also secures him an opportunity to discharge religious duties. As he is a merchant, his opportunity to perform religious duties, thus, appears in the form of his generosity. "He was open to everything people brought to him. He received the merchant who bought him linen for sale. He received the debtor who looked for a loan. He received the beggar who spent an hour telling him the story of his poverty.'”[5]

On the whole, the pursuit of artha in Siddhartha not only secures the protagonist a legitimate requirement of human nature, but also dignity and a chance to perform religious duties.

\section{The pursuit of dharma in Siddhartha}

As dharma is the highest of worldly aims, the pursuit of dharma is concerned with the whole context of religious and moral duties. This objective is sought when the protagonist lives the life of a forest-dweller.

His dharma pursuit is marked by hearing the word Om, the holy word of Hinduism. After Siddhartha arrives at the river bank and decides to commit suicide, he suddenly hears the word Om and then has a deep sleep. Hearing the word Om and having a deep sleep, in this sense, connotes his spiritual awakening, dharma rebirth, and the shift to dharma life.

In the aspect of his dharma pursuit, the protagonist discovers that dharma reveals itself in the river as the laws of nature: "He saw: the river ran incessantly, but was always there. It was the same all the time and yet new in every moment."[5] This discovery encourages him to learn more from it. He then learns to live a modest life considered to be a naturalistic element of dharma practice: "He learned to build oars, to mend the boat and to weave baskets. He was pleased because of everything he learned and did. The days and months passed quickly."[5] The humble life is regarded as the obligation and moral oughtness in his dharma life. Moreover, his contemplation on Kamala's death also secures him the understanding of dharma as essential property/disposition: "Keenly he felt, in this hour, the imperishableness of every life, the timelessness of every moment."[5] That is: the eternity of the soul or atman which continues to exist.

Thus, the pursuit of dharma in Siddhartha represents his spiritual awakening, the shift to dharma life, and the acquisition of higher knowledge which prepares him for the final human stage.

\section{The pursuit of moksha in Siddhartha}

The pursuit of moksha in Siddhartha arises from the desire to become emancipated from his suffering. This suffering is the result of his karma which the protagonist had done to his father: 
"Did he not expect the same fate? Was it not a comedy, a strange and stupid thing, this repetition, this course of events in a fateful circle?"[5]

After the protagonist realizes the cause of his suffering, he returns to the hut and confesses everything to Vasudeva. Vasudeva then leads him to the river bank, suggests that he listen to the river. At this point, listening to the river denotes meditation practice or the process of cultivation of right understanding. This aims at the realization of the true self which finally appears in the form of the holy word Om: "When he neither listened to the laughter nor the sorrow, when he did not tie his soul to any particular voice and let his Self-submerged into it, but when he heard them all, the oneness; then the great song of a thousand voices consisted of a single word: Om -perfection."'[5] This is considered to be the essential duty regulated by purushartha. That is: one must secure himself with the attainment of moksha in order to get emancipated from samsara.

The pursuit of moksha presents his effort to become liberated from suffering caused by karma. His suffering is eliminated by the means of spiritual practice. The attainment of moksha becomes the highest end of his quest.

Siddhartha clearly represents the pursuit of good things for human. The protagonist seeks and experiences kama through sex and good living. He pursues artha as a mean to a comfortable life, dignity and self-respect, and the opportunity to perform religious duties. He seeks dharma in order to prepare himself for the final human stage. Finally, he pursues moksha in order to escape from human bondages and fulfills the last duty of human life.

\section{Jnana-marga as Siddhartha's path to liberation}

In Siddhartha, the practice of jnana-marga appears in the last two stages of his life. The protagonist who has a strong reflective incline decides to learn from the river. Under the guidance of Vasudeva, the protagonist pursuits the four means regarded as the stage of cultivation of detachment. He first equips himself with the practice of Vairagya or dispassion.

"To listen with a quiet heart, with a waiting, opened soul, without feeling, without a wish, without judgment, without an opinion is what he learned from it."[5] This practice brings about his non-attachment to sensual objects. Afterwards the protagonist practices Viveka or the discrimination between the real and unreal that enables him to realize that time is illusion.

"Everything is presence and has reality. Nothing was or will be."[5] Siddhartha then proceeds to the third mean or Shat-Sampat. His first virtue or Sama is presented through his tranquility towards Kamala's death. Vasudeva also remarks his Sama that "Siddhartha, you have suffered but I see no sadness in your heart."[5] His second virtue or Dama is portrayed through the effort to win the heart of his spoiled son who leads him to the realization of his sameness with other people. "Since the son was there, Siddhartha had become entirely like one of the people through suffering and loving."[5] The practice of the third virtue or Uparati makes him understand that the attachment to sense organs (his son) and sensual pleasures (the town) leads to suffering.

"There was only emptiness instead of the desired goal which had drawn him here after his son."[5] This realization brings about the withdrawal from sensual pleasures. The practice of fourth virtue or Titiksha is conveyed through his endurance towards the wound, the symbol of 
his karma. "He silently spoke the word Om, filled himself with Om when he felt the pain from the wound."[5] The fifth virtue following the practice of Titiksha is his Sraddha. This is shown through his faith in Vasudeva. "Nevertheless, he felt hope. He felt an undefeatable desire to confess to Vasudeva once he had returned to the hut. He wanted to disclose and tell everything to the man who knew how to listen.'[5] The sixth virtue or Samadhana is represented through his contemplation on the characteristic of Vasudeva who gradually reveals the knowledge of the Self. "The more he realized that everything was natural and in order, the more he found that Vasudeva was God Himself. He was indeed indifferent from him.'[5] This realization generates the strong desire for liberation or Mumukshutva.

After accomplishing the stage of cultivation of detachment, Vasudeva leads the protagonist to the seat on the river bank, which is comparable to sitting at the lotus-feet of a guru. He then listens to the river as if he were hearing the scriptures. In the first step, he realizes that all things have to suffer in the flux of samsara. "All of them were part of the river. It was their goal to yearn, to desire, and to suffer. The voice of the river was full of longing, smarting woe, and insatiable desire."[5] In the second step, he practices reflection which dispels his doubts and enables him to understand the duality of all things. "All voices, all goals, all yearning, all suffering, all pleasure, and all that was good and evil, all of this together was the world.'[5] In the last step, the protagonist practices deep meditation on Brahman and realizes the real essence of everything. "When he neither listened to the laughter nor the sorrow, when he did not tie his soul to any particular voice and let his Self-submerged into it, but when he heard them all, the oneness; then the great song of a thousand voices consisted of a single word: Om -- perfection."[5] The direct realization of the identity of his self and Brahman leads him to the state of spiritual liberation. He finally becomes a Jivanmukti.

Siddhartha also presents jnana-marga or the path of knowledge as a mean to liberation. He, in the first step, provides himself with the four means: non-attachment to sensual objects (Vairagya), discrimination of the real and unreal (Viveka), the six virtues (Shat-Sampat), and strong yearning for liberation (Mumukshutva). In the second step, he listens to the river (hearing), discerns the duality of all things (reflection), and discerns the true nature of everything (doing deep meditation on Brahman).

\section{CONCLUSION}

The concepts on the quest for spiritual liberation of Hinduism and Siddhartha's quest for moksha in Hesse's novel share some similarities. The first is Siddhartha's quest depicts asramas or the four stages of life as related to his ages and duties. In the stage of brahmacarya, Siddhartha spends his boyhood with religious study and self-discipline under the guidance of Brahmins and sramanas. In the stage of grhastha, he spends his adult age dealing with the three realms: family, vocation, and community. He has Kamala as his lover, works with Kamaswami to earn his living, and supports other people in the community he belongs to. In the stage of vanaprasthya, the protagonist renounces all of his worldly possessions and concerns and lives by the river in order to begin his spiritual quest under the guidance of Vasudeva. In the stage of sannyasin, he spends his old age with spiritual practice. After he attains liberation, he teaches and helps Govinda attain enlightenment. 
Siddhartha's quest also presents the pursuit of purushartha or the four objectives of life. In the pursuit of kama, Siddhartha seeks and experiences kama through sex and good living. He learns about love from Kamala and enjoys himself with many kinds of worldly enjoyment: wearing beautiful clothes, bathing in perfumed water, eating fine food, etc. In the pursuit of artha, Siddhartha spends years working with Kamaswami. Artha secures him a comfortable life, dignity and self-respect, and the possibility to perform moral duties. In the pursuit of dharma, he leads a life of a ferryman, learns spiritual aspects from the river and Vasudeva. And in the pursuit of moksha, he practices meditation in order to get liberated from the retribution of his own karma. Finally, Siddhartha's quest portrays the means to liberation through jnana-marga or the path of knowledge. He first equips himself with the four means. He practices non-attachment to sensual object (Vairagya), discerns that time is illusion (Viveka), cultivates the six virtues (Shat-Sampat) by showing tranquility towards Kamala's death (Sama), trying to win his son's heart (Dama), letting his son go on his way (Uparati), enduring his own karma (Titiksha), having faith in Vasudeva (Sraddha), contemplating on Vasudeva's characteristics (Samadhana), and desiring for liberation (Mumukshutva). In the stage of acquisition of knowledge, Siddhartha first listens to the river (hearing the scriptures). He then discerns the duality of all things (reflection). Finally, he realizes that Brahman dwells in everything (doing deep meditation on Brahman). This direct realization of the true Self leads him to the attainment of moksha.

The concepts on the pursuit of liberation of Hinduism and Siddhartha's quest for moksha are intended to present the ideal way of life which includes secular aspects and spiritual aspects altogether. Most of all, they also demonstrate that humans can overcome all worldly bondages and transform into the perfect human.

\section{ACKNOWLEDGEMENT}

I would never have been able to finish my thesis on which is article is based without the guidance of my committee members, help from friends, and support from my family. I would like to thank my advisor, Dr. Prommintra Kongkaew, for his invaluable guidance, engagement, and encouragement throughout my thesis project. I really appreciate the amount of time he spent reading drafts, giving advice, and discussing my future. He is indeed an "ideal" advisor who paid attention not only to my academic development, but also my real life. Without him, I would not have achieved this far and this thesis would not have been completed. Words cannot sufficiently describe his kindness to me and my gratitude to him. Next, I would like to extend my thanks to Asst. Prof. Rungthip Anmai, then Ajarn Praichon Intanujit, then Ajarn Sunida Supantamart, then Dr. Ram Prasansak, then all of my teachers and classmates in the Master's Degree Program of Arts in English.

\section{REFERENCES}

[1] Aurobindo, S. The Life Divine. 22nd ed. Pondicherry: Sri Aurobindo Ashram Press, 2010, 28.

[2] Coward, H. Sin and Salvation in the World Religions. 1st ed. Oxford: Oneworld Publications; 2003, 90, 94, 95, 95.

[3] De La Torre, Miguel A. The Hope of Liberation in World Religions. 1st ed. Texas: Baylor University Press, 2008, 114, 114, 115. 
[4] Grimes, J. A Concise Dictionary of Indian Philosophy. 1st ed. Albany: State University of New York Press, 1996, 158.

[5] Hesse, H. Siddhartha. 4th ed. New Delhi: Rupa.Co, 2006, 3, 13, 56, 60, 56, 56, 59, 66, $69,87,87,109,114,115,60,63,55,57,58,83,87,94,106,109,87,88,94,99,102-$ 103, 103, 106-10, 107-108, 108, 109, 109.

[6] Klostermaier, Klaus K. Hinduism: A beginner's Guide. 2nd ed. Oxford: Oneworld Publication, 2007, 35.

[7] Klostermaier, Klaus K. A Survey of Hinduism. 3rd ed. Albany: State University of New York Press, 2007, 291.

[8] Lal, V. Introducing Hinduism. 1st ed. London: Icon Books Ltd, 2001, 48.

[9] Matthews, W. World Religions. 7th ed. Belmont: Wadsworth, 2013, 84.

[10] Mittal, Sushil and Gene Thursby. Religions of South Asia. 1st ed. New York: Routledge, 2006, 80, 59, 20, 61.

[11] Promta, S. Hinduism: A Short Introduction, Wisdom Magazine, Vol. 13, No. 1, March 2011, 36.

[12] Rinehart, R. Contemporary Hinduism: Ritual, Culture, and Practice. 1st ed. Santa Barbara: ABC-CLIO,Inc., 2004, 160, 160, 162-165, 161.

[13] Robinson, James B. Hinduism. 1st ed. Philadelphia: Chelsea House Publishers, 2004, 41.

[14] Singh, K. Spirituality: What it is. 8th ed. Blaine: Print Graphics Pros, 2005, 39.

[15] Sivananda, Sri Swami. All about Hinduism. 7th ed. Himalayas: The Divine Life Society, 1999, 33, 35, 36, 36, 81, 81, 81.

[16] Smith, H. The World's Religions. 2nd ed. New York: Harper Collins, 1991, 51, 51, 29.

[17] Tolle, E. A New Earth: Awakening to Your Life's Purpose. 1st ed. New York: Oprah's Book Club, 2005, 25.

[18] Zimmer, H. Philosophies of India. $2 n$ d ed. London: Routledge, 1953, 157, 35, 41. 